VALENTINA M. GAVRANOVIĆ ${ }^{1}$

Marijana M. Prodanović

SINGIDUNUM UNIVERSITY

DEPARTMENT OF ENGLISH LANGUAGE

\title{
THE DIACHRONIC PERSPECTIVE ON THE MORPHOLOGY OF COMPOUND ADJECTIVES
}

\begin{abstract}
This paper focuses on a diachronic study of compound adjectives found in the Old and Middle English texts of the Helsinki Corpus. The compound adjectives of both periods are analysed, and further classified into types on the basis of the word class their constituent elements belong to. The aim of the research is to follow the development courses of compound adjective types in the two language periods and to investigate what happened to them in Modern English. The comparison of the types results in the description of the character of these changes, illuminating which Old English types survived into the subsequent periods, which were lost from the language, and what were the new ones introduced in the Middle English period.
\end{abstract}

KEYWORDS: compound adjective; word class; corpus; change.

INTRODUCTION

Language change, as an on-going phenomenon, is characteristic of all languages, and the modern English language we know today results from over fifteen hundred years of development, influenced by various social, political, and cultural events which marked the

vgavranovic@singidunum.ac.rs

mprodanovic@singidunum.ac.rs

This paper was submitted on January $6^{\text {th }}, 2021$ and accepted for publication at the meeting of the Editorial Board held on November $16^{\text {th }}, 2011$. 
history of Great Britain. The English language has changed significantly throughout its long history, and the most obvious changes are observed in the domain of its vocabulary-it has been estimated that $85 \%$ of Old English words of German origin were lost (Kastovsky, 2005). Linguistic reasons for these changes can be attributed to borrowing and different word-formation processes, and compounding takes an important part and effects the structure and outlook of the English word stock. Even though compounding has demonstrated a most productive potential in English word-formation, it raises many unresolved issues-the domain of diachrony, and morphological structure being some of them. Furthermore, not all parts of speech gained the same attention in research-adjectival compounds have been neglected in morphological studies in comparison to the most widely studied nominal compounds.

This paper focuses on a diachronic aspect of compounding-the description of compound adjective types in Old and Middle English, based on parts of speech their constituent elements belong to. The aim of the study is to describe the nature of development courses of compound adjective types during these two language periods, and to find out which Old English patterns survived into Middle and Modern English, and which ones died out of the language. Although compounds and elements they are composed of evolve in time and undergo changes occurring at all linguistic levels, in this work we will focus on changes affecting compounds only in terms of parts of speech their constituent elements belong to, with the aim to investigate language change affecting language inner structure, and how susceptible it is to change.

The research relies on the study of texts from the diachronic part of the Helsinki Corpus, the most thorough and relevant corpus representing English throughout its history. The compound adjectives analysed in this work were taken from the Old and Middle English texts of the Corpus, dating from 750 to 1150 , and from 1150 to 1500 , respectively.

\section{THEORETICAL BACKGROUND}

The present influence of the English language is not a novel onethe language has been gaining and retaining influence over the centuries; however, apart from the influence, the centuries also brought countless contacts with a number of languages the speak- 
ers of which visited or ruled over the territories related to the English language. As a result, over the long period of its existence, English has 'changed substantially [...] reflecting the patterns of contact with other languages' (Graddol, 2000, p. 2). Although it has, undisputedly, occupied the position of the global lingua franca, there are actually very few words which could be regarded as autochthonous within the vocabulary of the contemporary English language. Despite the fact that 'hybridity and permeability' of English, stemming from its openness, are regarded as 'defining features' (Graddol, 2000, p. 6), it is believed that these very traits make it, not only vibrant but also vulnerable. Furthermore, hand in hand with characteristics brought along with the mentioned contacts, English has kept evolving as a result of changes which are intricately connected with various linguistic processes and mechanisms developing at all linguistic levels.

Even though the language spoken at the outset (5-7 c.) of English language development is described as primitive, its successor, i.e., Early Old English (7-10 c.), along with Late Old English (10 \& 11 c.) witnessed the introduction of the very first literary texts (Stumpf, 1970; Graddol, 2000). Relying on the fact that compounding has been found to be an inherent component, and a rather prolific device within the scopes of Old English poetry (Chapman \& Christensen, 2007, p. 447), we could say that the language used for the stated purposes was by no means dull.

The linguistic device of compounding has always been a thought-provoking phenomenon for theorists addressing word formation processes. Applied from the very birth of the written word in English, and irrespective of the fact that $85 \%$ of the language corpus used back in Old English is not a part of the language we speak nowadays, the process of merging words has been preserved intact (Baugh, 1951).

Much has been written about the process of compounding in linguistic studies and investigations ever since linguistics was founded as a science with its strict scientific method. It has been studied within various linguistic frameworks, and the classification was based on some of the linguistic considerations - semantic, syntactic or morphological (Lieber 2009). The complex layers belonging to different linguistic levels, and their intersections, make the study and the analysis of compounds challenging and, at times, elusive because compounds cannot be clearly positioned within grammar. They combine several complementing areas, such as syntagmatic 
and paradigmatic relations, syntax and morphology, and both linguistic and non-linguistic, or pragmatic knowledge (Scalise, 2010, p. 2). As a result of these complexities, Algeo positions compounds between the area of lexis and grammar, and says that it is "part vocabulary, and part syntax' (Algeo, 2007, p. 74).

Due to the complex nature of compounds, it is difficult to define them in a straightforward and precise way. Many linguists relied on word-based definitions, and the earliest of such kind was given by Morris: 'Two or more words are joined together to make a single term expressing a new notion' (Morris, 1873, p. 221). Hans Marchand also defined compounds using words to describe their constituent elements: "When two or more words are combined into a morphological unit we speak of a compound' (Marchand, 1960, p. 11). Another very common concept used by linguists to define compounds was 'lexeme', and one of the examples illustrating it was the definition given by Matthews, who described compounding as a lexical process 'by which a compound lexeme is derived from two or more simple lexemes' (Matthews, 1974, p. 82).

Yet, somehow, these definitions cannot completely account for all compound characteristics and, thus, other criteria were often used in linguistic explanations-both syntactic and semantic considerations being very important, and, therefore, the definition given by Pyles attributes to a better understanding: 'Putting two or more words together to make a new word with a meaning in some way different, [...]' (Pyles, 1964, p. 276). In a similar vein, Scalise defined compounds as syntactic-semantic islands, perceived as conceptual units with a specific accent (Scalise, 2010, p. 6).

Anyhow, though omnipresent, almost palpable within the scope of word formation and very productive in languages like English or German (as well as in some clearly unrelated language, such as Hmnong) (Yule, 2017, p. 172), compounding, as mentioned earlier, due to its rather vague characteristics, has not managed to lay down straight-forward guidelines on the manner in which we should approach it.

Namely, hardly could we find any accurate criteria for the recognition, i.e., formation of compounds (Lieber \& Štekauer, 2009, p. 5), despite considerable effort and continuous research on the issue. In addition, it could be said that several microlinguistic disciplines joined forces to shed more light on the notion of compoundhood; it has been concluded that neither orthographic criteria (e.g., the implementation of a hyphen, seen as a prevailing mechanism for 
some types of compounds in the contemporary English language (Jovanovic, 2005), nor headedness suffice, furthermore, they can differ 'even within a single language' and the English language is one of those emitting inconsistencies as regards the matter (Lieber \& Štekauer, 2009, pp. 6-7).

Stress was also used as a means of differentiation-then again, in spite of a number of rules stating when to apply Initial or Final Element Stress pattern, i.e., left- or right-hand stress, the practice has still remained open to questions. In addition to orthographic, phonological, and morphological criteria, the mechanisms of semantics and syntax have also been applied with the goal of making a positive identification of compoundhood; their failure to do so, has led some theorists to the conclusion that, at least in English, 'there is no such thing as a compound' (Spencer, as cited in Lieber \& Štekauer, 2009, p. 17).

Another much debated aspect of compounds refers to their classification, and various criteria have been proposed: grammatical relation between constituent elements, semantic and syntactic characteristics, parts of speech of a compound as a whole, and of its constituent elements, and headedness. The formal classification of compounds based on parts of speech, though with some drawbacks, has pragmatic values and clarifies the phenomenon of compounding from one perspective, contributing to creating a more comprehensive picture.

\section{METHODOLOGY AND RESEARCH RESULTS}

The research focuses on the morphological analysis of compound adjectives found in the Old and Middle English texts of the Helsinki Corpus, dating from 750 to 1150 , and from 1150 to 1500 , respectively. The length of the texts varies: shorter texts are cited in toto, while the longer ones are fragmented, their length ranging from 2000 to 10000 words. The material of the Helsinki Corpus used in this work was obtained from Oxford Text Archive, and the authors searched the compounds in a traditional way, with no computational or search tools tool options.

The analysis of compound adjectives taken from the Corpus relies upon relevant Old and Middle English dictionaries: The Dictionary of Old English (DOE), which defines English vocabulary from 600 to 1150, giving a comprehensive account of words which ever 
appeared in any type of texts of the Anglo-Saxon period, Bosworth-Toller's An Anglo-Saxon Dictionary Online, and Hall's Concise Anglo-Saxon Dictionary; for the analysis of Middle English compounds we used Middle English Dictionary, in the electronic version, which covers vocabulary dating from 1100 to 1500 , and Bradley's Middle English dictionary.

When a lexical item from each period was defined as an adjectival compound, it was classified into a certain type on the basis of the parts of speech their constituent elements-determinant and determinatum-belong to. Subsequently, these types were compared and the development courses were described at different levels: adjectival compound types which died out of the English language; adjectival compound types which survived into Middle and Modern English; and the emergence of new patterns in Middle English. The research aims not only at describing these types and changes in different language periods, but, also, at examining the number of examples found for each type, which provides a better insight into their productivity.

Since this study examines formal properties of compound adjectives, it does not include phrasal formations which exemplify syntactic conversion and adjectives coordinated with the conjunction 'and'.

\section{OLD ENGLISH ADJECTIVAL COMPOUND TYPES}

The total number of compound adjectives found in the Old English texts of the Corpus amounts to more than 200. The morphological analysis based on the parts of speech their constituents belong to shows that Old English compound adjectives can be classified into 11 subtypes. The following table shows the types of compound adjectives found in the Corpus, and the number of examples found for each type:

\begin{tabular}{||l|l|}
\hline \multicolumn{1}{|c|}{ TYPE } & \multicolumn{1}{|c|}{ EXAMPLE } \\
\hline noun+adjective (80) & $\begin{array}{l}\text { goldhwoet 'greedy for gold'< gold, n. 'gold' + hwcet, adj. 'quick, ac- } \\
\text { tive' }\end{array}$ \\
\hline adverb+adjective (33) & $\begin{array}{l}\text { ofermicel 'over much, excessive'< ofer, adv. 'above, over' + micel, } \\
\text { adj. 'great' }\end{array}$ \\
\hline \hline
\end{tabular}

TABLE 1: COMPOUND ADJECTIVE TYPES IN OLD ENGLISH 


\begin{tabular}{|l|l|}
\hline adjective+adjective (30) & $\begin{array}{l}\text { druncengeorn 'intoxicated, drunken'< druncen, adj. 'drunk' + georn } \\
\text { 'eager, desirous' }\end{array}$ \\
\hline $\begin{array}{l}\text { adjective+noun (30) } \\
\text { adjective+past participle } \\
(13)\end{array}$ & $\begin{array}{l}\text { frumcenned 'first-born, eldest'< frum, adj. 'first, original' + cenned, } \\
\text { past participle of the verb cennan 'to bear, bring forth' }\end{array}$ \\
\hline adverb+participle (5) & $\begin{array}{l}\text { dunestigende 'descending'< dune, adv. 'down' + astigende, present } \\
\text { participle of the verb astigan 'to go, come, step' }\end{array}$ \\
\hline $\begin{array}{l}\text { noun+present participle } \\
\text { (4) }\end{array}$ & $\begin{array}{l}\text { foldhrerende, adj. 'earth-stirring, trading the ground'< folde, n. } \\
\text { 'the earth, gorund' + hrerende, present participle of the verb } \\
\text { hrēran 'to move shake, stir' }\end{array}$ \\
\hline $\begin{array}{l}\text { number+adjective/ noun } \\
\text { (4) }\end{array}$ & $\begin{array}{l}\text { feowerscyte 'four-cornered, square'< feower, number 'four' + scyte, } \\
\text { n. 'shooting' }\end{array}$ \\
\hline past participle+noun (3) & $\begin{array}{l}\text { collenferhð'fierce-minded, bold of spirit'< collen, past participle of } \\
\text { the verb cellan 'to swell' + ferhð, n. 'soul, spirit' }\end{array}$ \\
\hline adverb+noun (3) & $\begin{array}{l}\text { oferhleoðor 'not hearing, inattentive to sound'< ofer, adv. 'above, } \\
\text { over' + hleoðor, n. 'hearing' }\end{array}$ \\
\hline noun+noun (2) & $\begin{array}{l}\text { calcrond/ calcrand 'round of hoof'< calc, n. 'shoe' + rond, n. 'border, } \\
\text { edge' }\end{array}$ \\
\hline \hline
\end{tabular}

TABLE 1: COMPOUND ADJECTIVE TYPES IN OLD ENGLISH

(1) The most productive type of compound adjectives is represented by a noun as the determinant and an adjective as the determinatum, and the relations between them are of various kinds, and the following examples show some of them: Jragbysig 'occupied for a time'< ðrag, n. 'a time, season' + bysig, adj. 'busy'; beaduscearp 'battle-sharp, sharp in fight'< beadu, n. 'battle, war' + scearp, adj. 'sharp'; deofolseoc 'devil-sick, possessed with a devil'< deofol, n. 'devil' + seoc, adj. 'sick'; firwetgeorn 'very inquisitive, curious'< firwet, n. 'curiosity' + georn, adj. 'eager'; noedderfah 'spotted like a snake'< noedre, n. 'serpent, snake' + fah, adj. 'coloured'. The last compound adjective shows that the determinant can have a slightly changed form when used as an independent morpheme.

(2) Another productive type of compound adjectives consists of an adverb as the determinant and an adjective as the determinatum. There are 33 compound adjectives of this type found in the Corpus, and the following examples illustrate the structure adverb + adjective: celmeahtig 'almighty'< cel, adv. 'all, wholly, completely' + meahtig, adj. 'mighty, powerful'; e.g. efenfela 'equally many so many, as many'<efen, adv. 'exactly, just' + fela, adj. 'much, many, a great 
number';forðsnoter 'very wise'< forð, adv. 'forwards, still' + snoter, adj. 'wise'; forehalig 'very holy'< fore, adv. 'before, in advance of' + halig, adj. 'holy'; sundorwis 'speacially wise'< sundor, adv. 'separately' + wise, adj. 'wise'; ymbhidig 'careful, anxious, feeling anxiety'< ymb, adv. 'about, by' + hygdig/ hydig, adj. 'disposed, minded'; eaðhylde 'satisfied, contended'< eaðe, adv. 'easily' + hylde, adj. 'inclined'.

Other productive types of Old English compound adjectives contain adjectival determinant, and the following structures are found in the Corpus:

(3) adjective + adjective, e.g., brunfag 'of a brown color'< brun, adj. 'brown' + fag, adj. 'coloured, dyed'; earmcearig 'wretched and sorrowful'<earm 'poor, miserable' + cearig 'sorrowful, wary'; ealdwerig 'vile of old'< eald, adj. 'old' + werig, adj. 'tired, exhausted'; eacencrceftig 'exceedingly strong'< eacen, adj. 'increased, great' + creftig, adj. 'skillful, powerful'. From the statistical point of view, the research shows that the pattern adjective + adjective was common, despite Blake's statement that it was 'thinly represented' in Old English (Blake, 2006, p. 443).

(4) adjective + noun, e.g., gamolfeax 'with hoary locks, grey-haired'< gamol, adj. 'old, aged' + feax, n. 'hair, the locks'; gloedmod 'glad-minded, cheerful'< gloed, adj. 'shining, bright' + mod, n. 'heart, mind, spirit'.

There are about 30 compound adjectives belonging to this type found in the Corpus. The commonest determinatum is mod, which is differently treated in dictionaries. In the DOE it is treated as an independent morpheme, while in Bosworth-Toller's Dictionary it is defined as a suffix, used in 'composition of adjectives'.

(5) adjective + past participle, e.g., wohbogen 'bent, crooked'< woh, adj.'bent, crooked, not straight' + bogen, past participle of the verb bugan 'to bend, to bow'.

Notwithstanding the small number of compound adjectives found in the Corpus representing other six types, the examples illustrate morphological characteristics of the period and are indicative of the potential the language had at the time, and how it evolved. The following examples illustrate the types:

(6) adverb + present/ past participle type, e.g., eðbegete 'easily got, prepared'<eð, adv. 'more easily' + begete, past participle of the verb begete 'to seize, obtain'; feorrancumen 'come from a far, stranger'< 
feorran, adv. 'afar, at a distance' + cumen, past participle of the verb cuman 'to come'.

(7) noun + present participle, e.g., landhoebbende, adj. 'owning land'< land, $\mathrm{n}$. 'land' + hoebbende, present participle of the verb habban 'to have, possess'; bordhcebbende, adj. 'bearing shields, equipped with shields'< bord, n. 'shield' + hoebbende, present participle of the verb habban 'to have, possess, hold, keep'; cnihtwesende, adj. 'being a boy, as a youth'< cniht, n. 'boy' + wesende, present participle of the verb bèon 'to be'.

(8) cardinal number + adjective/ noun - this type is not described in the literature, probably due to the adjectival function of the cardinal number in the position of the determinant. Only four examples are found in the Corpus: feowerfete, adj.'four-footed, quadruped'< feower, cardinal number, used as an adjective, meaning 'four' + fete, adj. 'having feet of a certain kind, provided with feet' (the second element fete is described as an adjectival suffix, used to form parasynthetic compounds (the DOE), and in Bosworth's Dictionary it is described both as an adjective and a suffix); fiðerfete 'four-footed'< fiðer, 'four' + fete, adj. 'provided with feet, footed' (on the other hand, the morpheme fiðer is defined as a prefix in Bosworth-Toller' Dictionary, used in the formation of compounds); seofonnihte, adj. 'seven days old'< seofon, number (with adjectival function) + nihte, $\mathrm{n}$. 'seven days'.

(9) past participle + noun, e.g., blandenfeax 'having mixed or grizzly hair, grey-haired'< blanden, past participle of the verb blandan 'to mix' + feax, n. 'hair'; bolgenmod 'enraged in mind'< bolgen, past participle of belgan 'enrage oneself, irritate oneself' + mod, n. 'heart, mind, spirit'.

(10) adverb + noun, e.g., eaðmod 'humble, obedient' < eaðe, adv. 'easily, readily' + mod, n. 'heart, mind, spirit'; oferhlyd, adj.'over-loud, noisy'< ofer, adv. + hlyd, n. 'sound'.

(11) noun + noun, e.g., weamod 'angry, wrathful'< wea, n. 'woe, misery' $+\bmod$, n. 'heart, mind, spirit'.

The analysis of compound adjectives found in the Corpus reveals types which are not defined in the cited studies. These types are: adverb + noun, adjective + noun (the research shows that this type was relatively productive compared to other types), noun + noun, adverb + participle, cardinal number + adjective/ noun, and past participle + noun. 


\section{MIDDLE ENGLISH ADJECTIVAL COMPOUND TYPES}

There are 65 compound adjectives found in the Middle English texts of the Helsinki Corpus, and on the basis of the parts of speech their constituent elements belong to they can classified into 8 subtypes. The Table 2 shows these subtypes, and the number of examples found for each:

\begin{tabular}{||l|l|}
\hline \multicolumn{1}{|c|}{ TYPE } & \multicolumn{1}{|c|}{ EXAMPLE } \\
\hline Noun+adjective (23) & $\begin{array}{l}\text { fot-lome, adj. 'lame in the foot'< fot, n. 'foot' + lome/lame, adj. } \\
\text { 'lame' }\end{array}$ \\
\hline Adverb + adjective (11) & ouer-cold, adj. 'too cold'< ouer, adv. 'over' + cold, adj. 'cold' \\
\hline Adj+adj (9) & $\begin{array}{l}\text { bayblak, adj. 'brown-black'< bay, adj. 'reddish brown + blak, adj. } \\
\text { 'black' }\end{array}$ \\
\hline Adjective+noun (9) & $\begin{array}{l}\text { mildheorrte, adj. 'merciful, kind'< mild, adj. 'kind, mild' + heorte, } \\
\text { n. 'heart', from OE mildheort }\end{array}$ \\
\hline $\begin{array}{l}\text { Adjective/ adverb + Past } \\
\text { Participle (7) }\end{array}$ & $\begin{array}{l}\text { neue-boren, adj. 'recently born'< neue, adv. 'newly, for the first } \\
\text { time' + boren, past participle of the verb berren 'to carry, bear' }\end{array}$ \\
\hline Noun + noun (3) & goddfriht, adj. 'god-fearing'<god, n. 'god' + friht, n. 'fear' \\
\hline Noun + Past Participle (2) & $\begin{array}{l}\text { gat-tothed, adj. 'having teeth set wide apart'< gat, from gate, n. } \\
\text { 'gateway' + tothed, past participle of the verb tothen 'to develop } \\
\text { or grow teeth' }\end{array}$ \\
\hline $\begin{array}{l}\text { Numeral + Past Participle } \\
\text { (1) }\end{array}$ & $\begin{array}{l}\text { foure-cornered 'four-cornered, rectangular'< foure, numeral } \\
\text { 'four' + cornered, past participle 'angular, pointed', from corner, } \\
\text { n }\end{array}$ \\
\hline \hline
\end{tabular}

TABLE 2: COMPOUND ADJECTIVE TYPES IN MIDDLE ENGLISH

(1) The most productive type, almost a third of the total number of compound adjectives analysed from the Corpus, consists of an adjective as a determinatum, modified by an adverb, and the following examples illustrate the type: nidthearf, adj. 'necessary, needful'< nid, n. 'need' + thearf, adj. 'in need, poor'; thredbare, adj. 'worn-out, shabby'< thred(e), n. 'fabric' + bar, adj. 'bare'.

Other common structures contain an adjective either as a determinant or determinatum, and the following types can be described:

(2) adverb + adjective, e.g., over-gret, adj. 'excessive in size, too great'< over, adv. 'over' + gret, adj. 'great'; thurh-drie, adj. 'completely dry'< thurh, adv. 'throughly, completely' + drie, adj. 'dry'. The commonest determinant is ouer/ over, and only two compounds 
consist of the adverb thurgh and an adjective. The adverbs usually have the intensifying function.

(3) adjective + adjective, e.g., dereworth/ derewurthe, adj. 'excellent, valuable'< dere, adj. 'excellent, noble' + worth, adj. 'worth, valuable';sothfast, adj. 'real, actual'< soth, adj. 'true, accurate, correct' + fast, adj. 'stable, secure'. The first adjective modifies the second one, providing an additional and subtle meaning to the determinatum.

(4) adjective + noun, e.g., dreri-mod, adj. 'sad at heart, dejected'<dre$r i$, adj. 'sorrowful, sad' + mod, n. 'mind, personality, heart'; neighonde, adj. 'near in space and time'< neigh, adj. 'near' + honde, n. 'human head, person, individual'.

(5) adjective/ adverb + Past participle, e.g., flat-crowped, adj. 'evenly cropped'< flat, adj. 'even, flat, smooth' + crowped, from croppen, vb. 'to trim, cut'; welcome, adj. 'welcome'< wel, adv. 'wel' + come/ cume, from the past participle of the verb comen 'to come'. This form is probably created under the influence of old French bienvenue $\mathrm{n}$., bienvenu, past participle.

The last three types were not so common, but, still, witness the existence of morphological structures in Middle English period:

(6) noun + noun, e.g., milfoil, adj. 'thousand-leaved'< mil, n. 'thousand' + foil, n. 'leaf'; tholemod, adj. 'patient, long-suffering'< thole, n. 'patience, forbearance' + mod, n. 'mind, heart'.

(7) noun + Past participle, e.g., kinebern, adj. 'of royal birth'< kine, from $\mathrm{OE}$ cyning, n. 'king' + bern, past participle of the verb beren 'to carry'.

(8) cardinal number + Past participle - only one example was found in the Corpus representing this type - foure-cornered.

The research casts light on new patterns for the creation of compound adjectives, which are not defined in the referred studies: adjective + noun (9), cardinal number + past participle (1), noun + noun (3), and adverb + adjective (11). On the other hand, Bradley (1955) defines two more types: verb base + noun, and verb base + adverb, but he does not give any example to illustrate the type. 


\section{DISCUSSION}

If we compare the types of compound adjectives found in old and Middle English, we can identify both quantitative and structural changes. First of all, the total number of compound adjectives found in the Middle English texts of the Corpus (66) is considerably smaller than the number of compound adjectives found in the old English texts (207)-the decrease in the number during the Middle English period is even sharper if the total number of the analysed words from both periods is to be considered. This finding also confirms the overall tendency related to a considerable decrease in the productivity of compounding as a morphological process during the Middle English period. It is also in compliance with the development of compound nouns, the number of which even more sharply declined in the Middle English period, with the ratio of almost 4:1 (Gavranović, 2015, pp. 59, 62).

Secondly, the analysis of the adjectival compound structures of both periods reveals several development tendencies: (1) more than a half of the Old English types for the creation of compound adjectives survived into Middle English; (2) some Old English types no longer produced compounds adjectives in Middle English; (3) some new structures were introduced in Middle English.

The Table 3 shows these types in both language periods illustrated by examples found in the corpus, and their counterparts in Modern English, if existent at all (represented either as the same adjective, with different spelling conventions, or the same type with a different example, if the OE or ME compound adjective did not survive into Modern English).

\begin{tabular}{|l|l|l|l|}
\hline \multicolumn{1}{|c|}{ TYPE } & \multicolumn{1}{|c|}{ OLD ENGLISH } & \multicolumn{1}{c|}{ MIDDLE ENGLISH } & \multicolumn{1}{c|}{ MODERN ENGLISH } \\
\hline noun + adjective & beaduscearp & nidthearf & homesick \\
\hline adverb + adjective & ofermicel & ouer-cold & overcold \\
\hline adjective + adjective & ealdwerig & bayblack & blue-green \\
\hline $\begin{array}{l}\text { adjective + noun } \\
\text { caljective/ adverb + } \\
\text { past/ present partici- } \\
\text { ple }\end{array}$ & $\begin{array}{l}\text { frumcenned/ eðbe- } \\
\text { gete }\end{array}$ & mildheorrte & short-term \\
\hline \hline
\end{tabular}

TABLE 3: THE DEVELOPMENT COURSES OF COMPOUND ADJECTIVES TYPES 


\begin{tabular}{|l|l|l|l|}
\hline noun + noun & weamod & goddfriht & part-time \\
\hline $\begin{array}{l}\text { noun/ adjective + } \\
\text { present participle }\end{array}$ & cnihtwesende & $/$ & breath-taking \\
\hline past participle + noun & bolgenmod & $/$ & $/$ \\
\hline $\begin{array}{l}\text { adverb + noun } \\
\text { cardinal number + } \\
\text { adjective/ noun }\end{array}$ & oferhlyd & $/$ & $/$ \\
\hline $\begin{array}{l}\text { cardinal number }+ \\
\text { past participle }\end{array}$ & $/$ & $/$ & five-week \\
\hline noun + past participle & $/$ & foure-cornered & four-cornered \\
\hline \hline
\end{tabular}

TABLE 3: THE DEVELOPMENT COURSES OF COMPOUND ADJECTIVES TYPES

(1) The most productive types of both OE and ME period were noun + adjective. What strikes most is approximately the same percentage represented in both periods: about a third of the total number of all compound adjectives found in the old and Middle English texts of the Corpus belongs to this type. Other types consisting of an adjective as one of the constituent elements (adjective + adjective, adjective + past participle, adverb + adjective, adjective + noun) also produced many compound adjectives in both periods. The proportion of types and the total number of compounds is approximately the same in both periods. The last type (noun + noun) was marginal in both periods.

The morphological analysis of Modern English compound adjectives includes several classifications, among which two types are defined as the commonest: one comprising an adjectival element (mainly being the head of the compound) and the other belonging to other lexical classes, such as noun, adverb, verb or other adjective, and another, defined as participial formations, composed of present or past participle as the right-hand constituent being preceded by a noun, adjective or an adverb. The description of Modern English compound adjectives proves the productive power of the surviving Old English patterns and the morphological possibilities they involve.

(2) The marginal old English types showed three possible development courses:

a. they did not survive into Middle English, and were never revived again in the English language. They showed the potential for the creation of compound adjectives only in Old English, 
and then died out. These types are: past participle + noun and adverb + noun.

b. OE types were no longer used to form new compound adjectives in Middle English, but they were revived again in the Modern English period. Such types are: noun/ adjective + present participle, past participle + noun, adverb + noun, and cardinal number + adjective.

c. even though marginal in Old English, they survived in both Middle and Modern English, and still exist and show a potential for new adjectival compound formations.

(3) The analysis of compound adjectives and the comparison of the existing types of the two periods show that there were some new structures introduced in Middle English: cardinal number + past participle, and noun + past participle, which survived into Modern English and are used today for the formation of new compound adjectives.

The main focus in this research was to determine structural types of compound adjectives throughout history, and to define changes occurring within these types. What strikes as a very common characteristic of these changes is the loss of compounds themselves (the number in Middle English period proves it), but what remained unchanged are the types-even though the words were lost from the language, the patterns used to form these compound adjectives still existed and produced new lexical items.

CONCLUSION Diachronic investigations greatly contribute to a better understanding of language phenomena, attributing to a more comprehensive insight into various linguistic aspects. However, a finite and conclusive description is difficult to attain in any linguistic endeavour, particularly those focusing on languages which existed in the past, as are old and Middle English. This study did not aspire to give a survey of all possible types of compounds which existed in these two language periods, but to investigate as many structures as they were found in the Helsinki Corpus, and to draw concluding remarks related to language change.

What strikes as the most obvious result of the research is of quantitative nature - the study of old and Middle English compound adjectives found in the Helsinki Corpus is in the compliance with the overall tendency of the use of compounds in Middle English, which was in decrease compared to Old English. Even though 
the total number of Middle English words in research is considerably bigger than the number of the Old English ones, the number of old English compound adjectives is more than three times bigger than the number of Middle English compound adjectives.

The analysis of the described adjectival compound types reveals several development courses: while the most productive types retained their potential for word formation in Middle and Modern English, the majority of marginal old English patterns went out of use. However, there were some Old English types which survived, but Old English compounds belonging to these types died out, and without a comparative analysis of these patterns one may come to the wrong conclusion that these types were new in Middle English. Finally, completely new patterns were introduced for formation of compound adjectives, and they survived into Modern English.

Although compounding in Middle English lost its productive power from the earlier period, it continued to enrich the vocabulary, and the analysis of the development of compound adjective structures shows that not only did the most productive types from Old English survive into Middle English, but they also continued to be more productive than other patterns in the subsequent language periods. The research supports the fact that despite the big Romance influence after the Norman Conquest, English preserved its original Germanic roots thanks to its inner structure - the findings support the characteristic of language change that the most susceptible to change are words, while the inner structure of language remains stable even after centuries of its development.

Algeo, J. (2007). Vocabulary. In: S. Romaine (ed.), The Cambridge History of the English Language (Vol. 4). Cambridge: Cambridge University Press.

Baugh, A. (1951). A History of the English Language. London: Routledge \& Kegan Paul.

Blake, N. (ed.). (2006). The Cambridge History of the English Language (Vol. 2). Cambridge: Cambridge University Press.

Bosworth, J. \& Northcote Toller, T. An Anglo-Saxon Dictionary Online. http:// www.bosworthtoller.com.

Bradley, H. (1891). Middle English Dictionary. Oxford: Oxford University Press.

Chapman, D. \& Christensen, R. (2007). Noun-Adjective Compounds as a Poetic Type in Old English. English Studies, 88 (4), 447-464. 
Hall, C. (1916). A Concise Anglo-Saxon Dictionary. $2^{\text {nd }}$ edition. http:// www.ling.upenn.edu/ kurisuto/germanic/oe_clarkhall_about.html.

Cameron, A. et al. (2007). Dictionary of Old English: A to G online. Toronto: University of Toronto. http://doe.utoronto.ca/pages/index.html.

Gavranović, V. (2015). Compound Nouns in Old and Middle English. Zbornik za jezike i književnosti Filozofskog fakulteta u Novom Sadu, 5 (5), 57-67.

Graddol, D. (2000). The Future of English. London: British Council.

Jovanovic, V. (2005). Morphological Aspects of English Adjectival Compounds: Corpus Analysis. Facta Universitatis Series: Linguistics and Literature, 3 (2), 209-226.

Kastovsky, D. (2005). Semantics and vocabulary. In: Hog, R. (ed.), The Cambridge History of the English Language I: The beginnings to 1066. Cambridge: Cambridge University Press.

Lieber, R. \& Stekauer, P. (2009). Oxford Handbook of Compounding. Oxford: Oxford University Press.

Marchand, H. (1960). The categories and types of present-day English word-formation, A synchronic-diachronic approach. Wiesbaden: Otto Harrassowitz.

Matthews, H. P. (1974). Morphology. An Introduction to the Theory of Word-Structure. Cambridge: Cambridge University Press.

The Middle English Dictionary. (2013). Michigan: University of Michigan. http://quod.lib.umich.edu/m/med/.

Morris, R. (1873). Historical Outlines of English Accidence. London: Macmillan and co.

Pyles, T. (1964). The Origins and Development of the English Language. New York: Harcourt, Brace \& World, Inc.

Scalise, S. \& Vogel, I. (2010). Cross-Disciplinary Issues in Compounding. Current Issues in Linguistic Theory 311. Amsterdam: John Benjamins Publishing Company.

Stumpf, J. (1970). An Outline of English Literature; Anglo-Saxon and Middle English Literature. London: Forum House Publishing Company

Yule, G. (2017). The Study of Language. Cambridge: Cambridge University Press.

OTHER

Rissanen, et al. (electronic resource).1991. The Helsinki Corpus. Helsiniki: DeSOURCES partment of Modern Languages, University of Helsinki.

ВАЛЕНТИНА М. ГАВРАНОВИЋ

МАРИЈАНА М. ПРОДАНОВИЋ 
Језичка промена представља важно обележје свих језика, и дијахрона проучавања знатно доприносе целовитијој слици описа језичких феномена и њиховом бољем разумевању. Енглески језик какав познајемо данас настао је као последица вишевековног развоја на свим нивоима језичке структуре, и на његову промену утицали су не само унутрашњи језички природни процеси већ и ठројни спољашњи - друштвени, политички и културолошки фактори.

Овај рад се ठави дијахронијским истраживањем сложених придева у староенглеским и средњоенглеским текстовима Хелсиншког корпуса, најрелевантнијег и најобухватнијег дијахроног корпуса енглеског језика. Прикупљени материјал је анализиран, а потом су сложени придеви описани и класификовани према врсти речи којој припадају њихови саставни елементи. Типови сложених придева оба периода су упоређени да $\delta$ се утврдило које промене су се одиграле током староенглеског и средњоенглеског периода. Овај рад за циљ има да прати развојне токове сложених придева током ова два језичка периода, и да истражи развојне токове типова сложених придева. Резултати истраживања показали су да су промене које су се одиграле двојаке - квантитативне и структуралне. Најочигледније промене тичу се $\delta$ роја сложених придева који је знатно мањи у средњоенглеском језику, упркос већем ठроју речи које припадају староенглеском делу Корпуса на којем је истраживање вршено. Упоредна анализа структуре сложених придева указује на неколико развојних тенденција: најпродуктивнији типови из староенглеског периода и даље су представљали најзаступљеније начине грађења сложених придева у средњоенглеском периоду; неки типови су ишчезли из језика, а неке нове структуре се почеле да се користе тек у средњоенглеском периоду. Важан резултат овог истраживања указује и на примере структура које су наставиле да постоје и у средњоенглеском периоду, али су староенглески сложени придеви који су настали према тим обрасцима ишчезли из језика, тако да би ठез дијахроног приступа проучавању ови староенглески обрасци могли ठити занемарени. Резултати овог истраживања показали су да, упркос снажном романском 
утицају у средњоенглеском периоду, главни обрасци грађења сложених придева задржавају своје германске корене, што потврђује став да се унутрашња структура језика теже мења.

КључнЕ РЕчи: сложени придев; врста речи; корпус; промена.

Овај чланак је објављен и дистрибуира се под лиценцом Creative Commons Ауторство-Некомерцијално Међународна 4.0 (CC BY-NC 4.0 |

https://creativecommons.org/licenses/by-nc/4.0/).

This paper is published and distributed under the terms and conditions of the Creative Commons Attribution-NonCommercial International 4.0 licence (CC BY-NC 4.0 | https://creativecommons.org/licenses/by-nc/4.0/). 